\title{
L'architettura vernacolare e i suoi linguaggi: verso un'ontologia dei centri storici minori
}

\author{
Ilaria Trizio \\ Adriana Marra \\ Francesca Savini \\ Andrea Ruggieri
}

Abstract

La natura poliedrica dei centri storici, conseguenza di aspetti eterogenei che riflettono circostanze ambientali e umane - come ad esempio l'orografia del terreno, le condizioni socio-economiche in relazione al divenire dei periodi storici, l'evoluzione delle tecniche e delle tecnologie della costruzione che partono dal sapere empirico, l'utilizzo prolungato e i cambi di destinazione d'uso delle forme insediative - costituisce sì un valore aggiunto, poiché li caratterizza e li rende unici, ma anche una problematica che apre varie sfaccettature, nella gestione e organizzazione delle operazioni volte alla loro conservazione. E indiscusso che per tutelare il patrimonio, sia esso un singolo bene o un complesso organismo quale un borgo, bisogna partire dalla conoscenza e quindi dai dati che derivano da indagini multidisciplinari. Ed è proprio per questo che è importante trovare un punto d'incontro che può risiedere nel definire l'architettura sistemica e nella standardizzazione dell'acquisizione dei dati. L'obiettivo che la ricerca vuole raggiungere ha orientato le operazioni verso una scomposizione dei centri storici che si declina su diverse scale: il singolo edificio, il complesso architettonico, il centro storico, le aree territoriali omogenee, i centri distanti ma accomunati da specifiche caratteristiche.

Parole chiave

ontologia, centri storici minori, linguaggi architettonici, patrimonio costruito, tecniche costruttive locali.

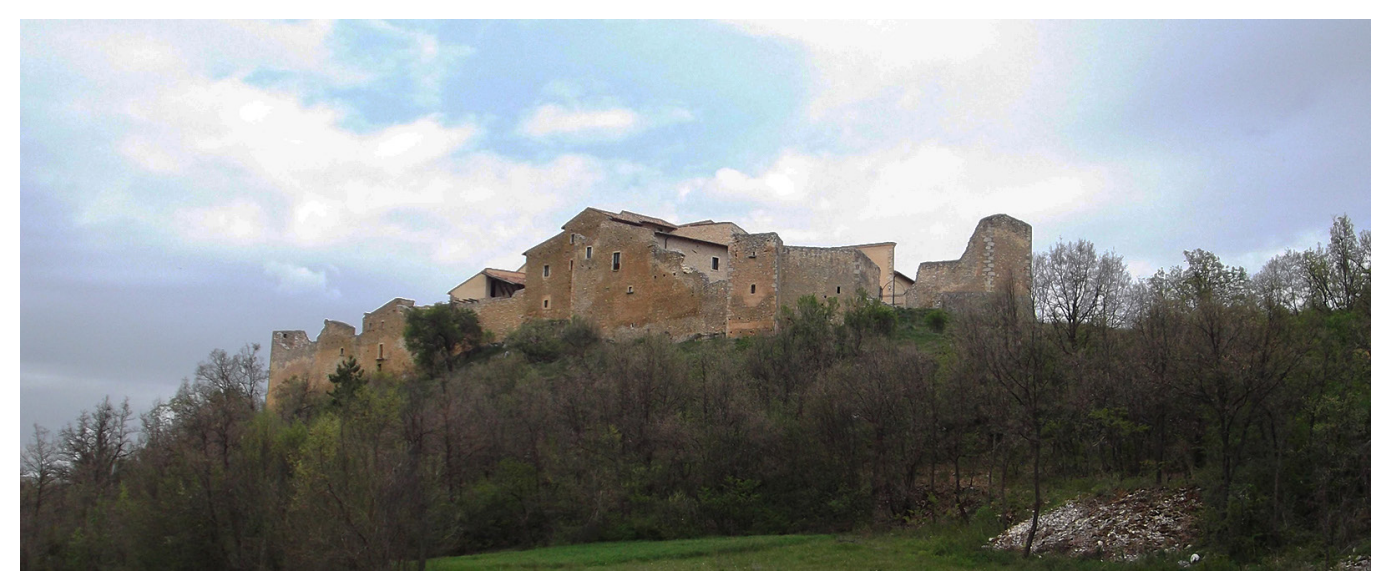




\section{Introduzione}

Nei processi di conservazione del costruito storico l'azione fondamentale da mettere in campo è rappresentata dalla conoscenza dei suoi aspetti morfologici e formali, che richiede maggiore attenzione quando si opera su scala territoriale, come nel caso dei centri storici minori presenti nelle aree interne nazionali. In questo contesto la conoscenza non va intesa come mera acquisizione di informazioni ma come un processo multidisciplinare e dinamico, in cui gli attori coinvolti collaborano per acquisire, integrare, e analizzare i dati necessari a ricostruire la storia evolutiva dei manufatti e del contesto territoriale in cui sono inseriti. Per poter assicurare la conservazione di tale patrimonio è necessario, da un lato, un costante aggiornamento dei dati acquisiti nella fase di documentazione e conoscenza e, dall'altro, l'individuazione di un lessico comune attraverso il quale condividere e implementare le innumerevoli informazioni. Questo sforzo è finalizzato a strutturare correttamente l'architettura dei dati e a garantire l'interoperabilità e la diffusione ad ampio raggio delle conoscenze acquisite. Inoltre, la costante evoluzione delle tecnologie digitali applicate al patrimonio culturale ha messo in evidenza i vantaggi derivanti dalla modellazione parametrica del costruito nella gestione e nello scambio dati in un unico modello tridimensionale [Oreni et al. 20।4; Dore, Murphy 20 I5; Brusaporci 2015 ] e, congiuntamente, per rappresentare adeguatamente il patrimonio informativo che deriva dalle analisi, si stanno esplorando le potenzialità del web semantico, attraverso la creazione di specifiche ontologie che consentono di ordinare gerarchicamente le informazioni e di descrivere in modo esaustivo i manufatti storici e i processi a essi connessi [Acierno et al. 20 17; Garozzo et al. 2017; Lo Turco et al. 2019].

A partire da queste considerazioni, il contributo illustra i risultati preliminari di una ricerca volta a definire un'ontologia in grado di documentare efficacemente il patrimonio costruttivo che contraddistingue il tessuto dei centri storici 'minori' abruzzesi [Trizio et al. 2020; Marra et al. 201 9; Savini, Fabbrocino, Marra 202 I], analizzandolo secondo più prospettive, da quella archeologica a quella urbanistica passando per quella architettonica. L'obiettivo dello studio è quello di definire una metodologia basata sulle ontologie che sia in grado di facilitare i processi di documentazione, conoscenza e conservazione del patrimonio costruito dei centri storici minori che possa essere esteso ad altri domini e facilmente integrato nei sistemi BIM. Si prevede in una fase successiva l'integrazione dei dati così strutturati in un ambiente digitale capace di connettere i modelli HBIM al GIS per la gestione multi-scalare dei centri storici, favorendone non solo la conoscenza ma anche il monitoraggio e la valutazione dei rischi cui questi sono maggiormente esposti.

Fig. I. Peculiarità costruttive dei centri minori abruzzesi: il borgo di Navelli (AQ) in alto; ( borgo di Castelvecchio (foto degli autori).

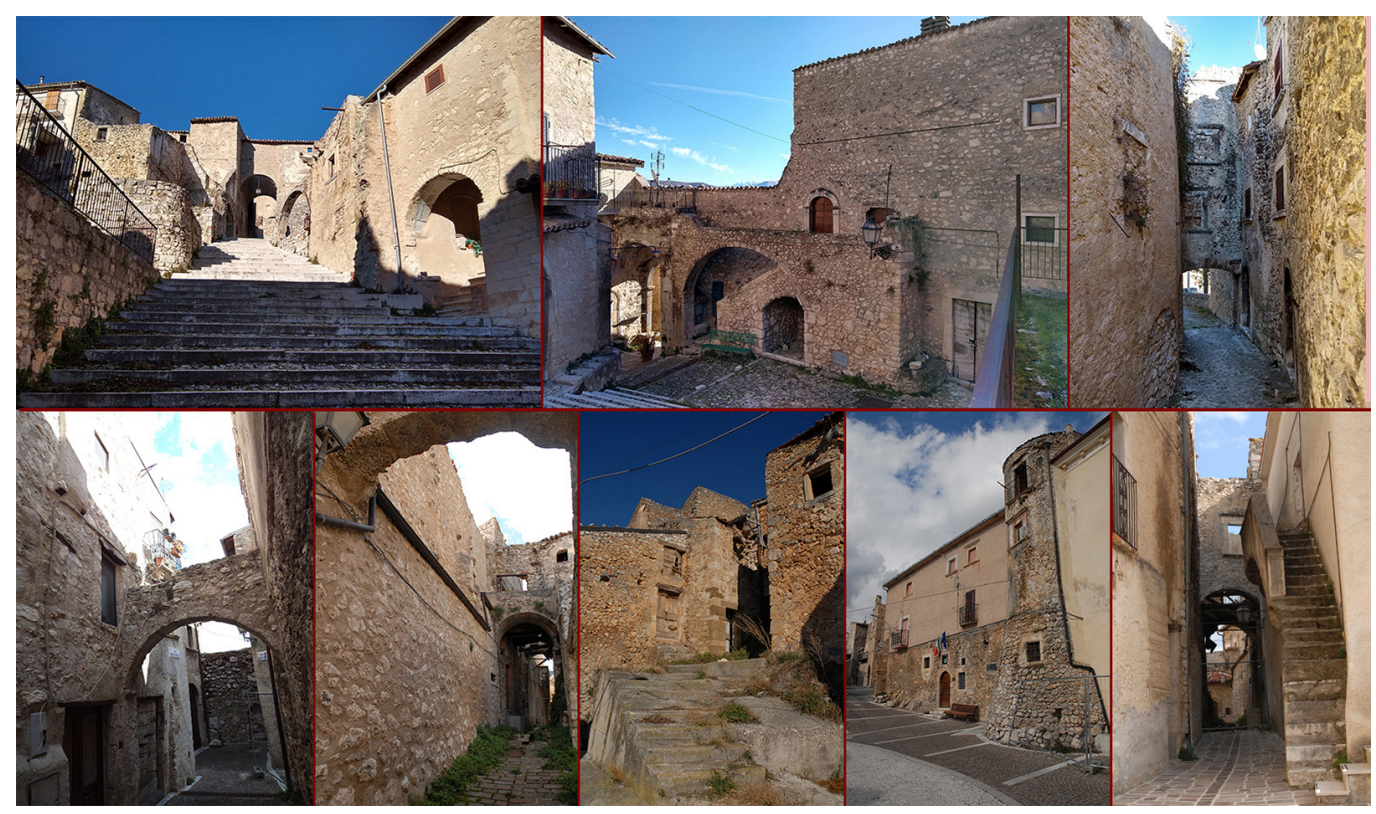


Fig. 2. Flowchart per lo sviluppo dell'ontologia per i centri minori (elaborazione degli autori).
Fig. 3.Tipologie edilizie identificate nei centri storici minori abruzzes: casa unifamiliare o casa in basso a sinistra:" "casa a schiera', in basso a destra (immagine asso a destra Caravaggio, Meda 2004, pp. 33-35)

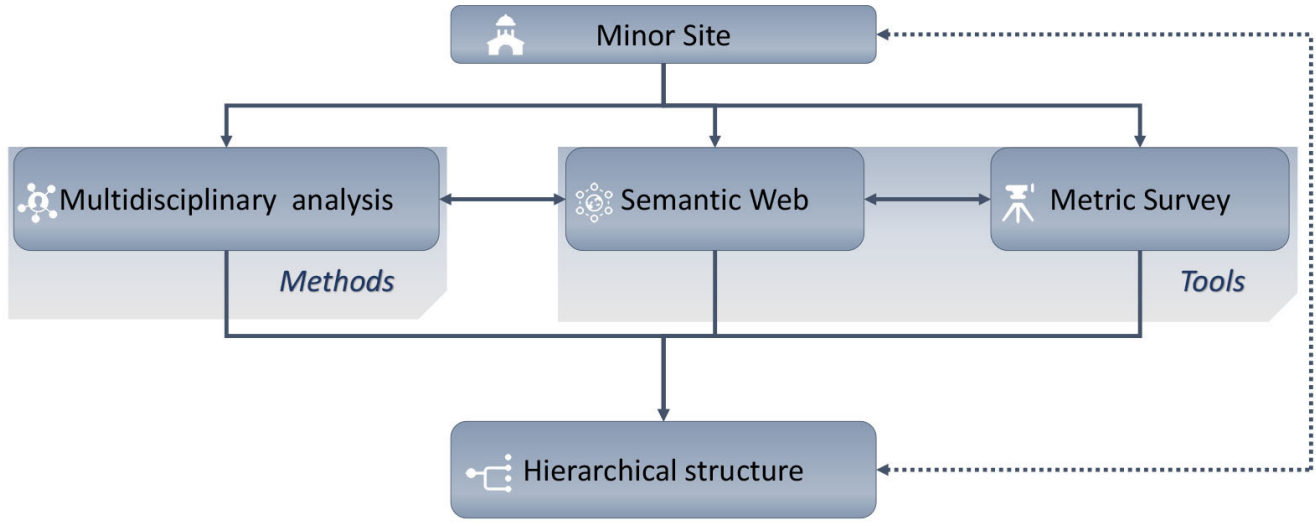

\section{Le ontologie per il patrimonio costruito storico}

Nel campo della conservazione dei beni culturali le possibilità offerte dalle ICT sono molteplici, e diretta conseguenza della loro applicazione è l'acquisizione, analisi e restituzione di una gran mole di dati eterogenei, spesso non integrati tra loro e inaccessibili, il cui utilizzo può essere ottimizzato optando per un approccio semantico che sfrutta gli strumenti messi a disposizione dal semantic web.

In particolare, si è diffuso l'uso delle ontologie. La parola 'ontologia' è suscettibile di diversi significati, considerando che è stata mutuata dal campo filosofico quale "studio dell'essere in quanto essere" [Lorhard 1606]. La declinazione di tale concetto nel campo dell'Intelligenza Artificiale (Al) ha portato alla definizione di ontologia come: "descrizione formale esplicita di concetti all'interno di un dominio di discussione (classi), proprietà che descrivono varie qualità e attributi dei concetti (slots), e vincoli sugli slots (facets)" [Novak-Marcincin, Gifu, Nicolescu 20 |4, p. 176].

L'ontologia di riferimento nel campo della conservazione dei beni culturali è il modello del CIDOC-CRM quale Conceptual Reference Model, definito nella sua versione più recente (release 7.0.1) come "una ontologia formale volta a facilitare l'integrazione, la mediazione e l'interscambio di informazioni eterogenee riguardanti il Patrimonio Culturale" [Doerr et al. 2020, p. i]. Dato che il CIDOC-CRM si propone di catalogare la documentazione relativa al patrimonio culturale, è stata avvertita, dalla comunità scientifica, la necessità di estenderlo e caratterizzarlo in funzione delle specificità e delle problematiche intrinseche di volta in volta riconosciute e conseguentemente affrontate.

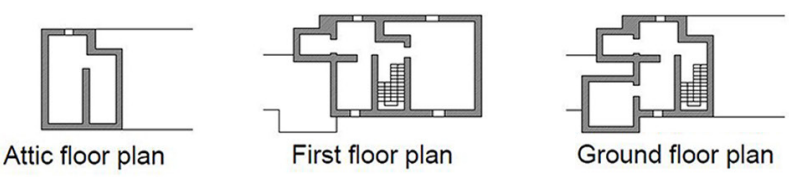

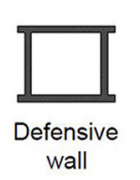
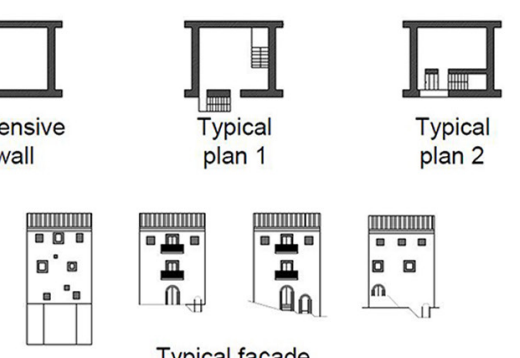

Typical façade
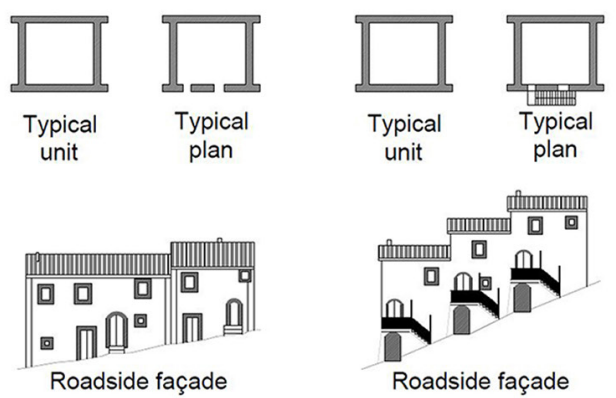
Scendendo nel campo specifico del costruito storico la letteratura è ricca di applicazioni sviluppate in ambiente HBIM, che prevedono un approccio ontology-based suscettibile di cambiare radicalmente il processo di modellazione e di provocare un sicuro impatto sulla qualità del contenuto informativo.

In rapporto ai temi della conservazione, è stato proposto un prototipo [Acierno et al. 20 I 7], che individua quattro principali domini di conoscenza (artefatto - ciclo di vita - processo di conoscenza del patrimonio architettonico - attori), successivamente connesso all'ambiente parametrico per offrire un'effettiva integrazione tra il modello ontologico e quello HBIM. II modello proposto evidenzia la necessità di considerare, nell'approcciarsi con l'architettura storica, la sua dimensione ermeneutica, e in tale direzione muove l'approccio (O)BHIMM che considera ogni componente dell'edificio nella sua specifica dimensione [Fiorani 20 I7]. Ulteriore applicazione del processo ontologico nell'ambiente parametrico riguarda la diretta connessione della knowledge base nelle famiglie di Revit, garantendo un linguaggio comune e interoperabile tramite procedimento semantico [Parisi, Lo Turco, Giovannini 20 19]. Un'estensione formale del CIDOC-CRM nel campo specifico del restauro e della con-

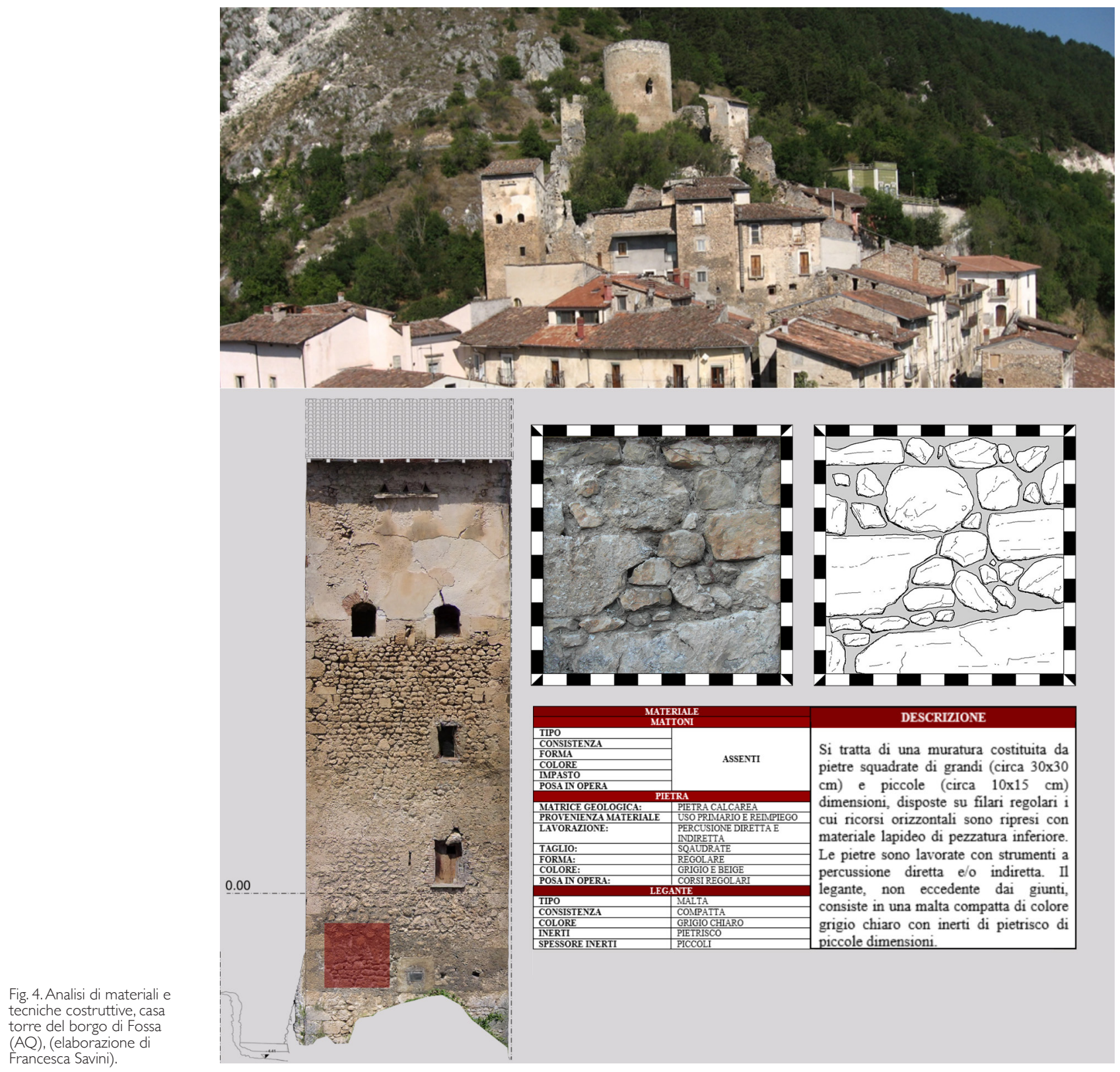


servazione dei beni culturali è il CRM ${ }_{C R}$ [Bannour et al. 20I8], un modello ontologico che si propone di descrivere il patrimonio attraverso le sue caratteristiche fondamentali quali la sua identità, le caratteristiche fisiche e la sua localizzazione all'interno di uno specifico contesto. Proprio riguardo la correlazione tra contenuto semantico e dimensione morfologico-spaziale del patrimonio costruito, è stata proposta una procedura di integrazione tramite l'utilizzo di un modello ontologico per le osservazioni multidisciplinari riguardanti lo stato di conservazione muovendo in direzione di una rappresentazione tridimensionale 'semanticamente consapevole' [Messaoudi et al. 20 I 8], per dare collocazione spaziale ai dati conservati nell'ontologia.

Un'ulteriore necessità è rappresentata dalla diffusione, e adozione su ampia scala delle ontologie create per il patrimonio culturale e in tal senso sono state implementate piattaforme e strumenti software [ArCo 2020; Garozzi et al. 2019], che consentono di rafforzare la collaborazione tra diversi enti e figure, incrementare quantità e qualità delle informazioni e incentivare una migliore fruizione del patrimonio.

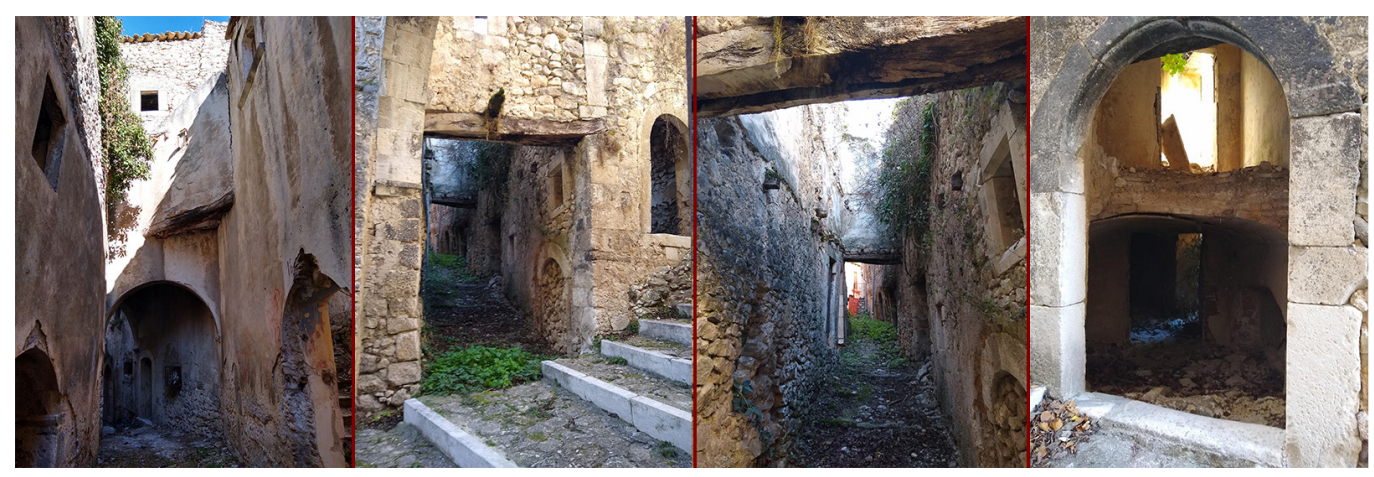

I caratteri peculiari dei centri storici minori: dall'analisi dei linguaggi alla progettazione di un'ontologia dedicata

La linea di ricerca che si sta portando avanti sui centri storici, con casi di studio nelle aree interne dell'Abruzzo e del Molise, è finalizzata alla definizione di strumenti di conoscenza sviluppati attraverso l'integrazione di linguaggi e metodi.Tali strumenti, individuati nei sistemi informativi in senso lato, sono orientati a supportare le amministrazioni locali nella definizione di strategie operative e nella scelta degli interventi di utilizzo/fruizione e conservazione. Da tale necessità, coniugata a quella di organizzare la ricerca in merito all'analisi multiscalare ha avuto origine lo sviluppo di una metodologia basata sulle ontologie, di cui si riportano in queste pagine alcuni risultati preliminari.

L'Abruzzo si contraddistingue per la presenza diffusa di aggregati storici di piccole dimensioni caratterizzati da un'edilizia 'povera', perfettamente integrata all'interno del contesto paesaggistico e ambientale, che ha acquistato nel tempo valori storici e culturali (fig. I), purtroppo significativamente compromessi da fenomeni legati allo spopolamento e dai ricorrenti eventi sismici [Varagnoli et al. 2020]. Numerosi sono gli studi editi che hanno analizzato le tipologie edilizie e le tecniche costruttive tradizionali dell'architettura abruzzese [Bonamico, Tamburini 1996; Zordan et al. 2002; Caravaggio, Meda 2004; Brusaporci 2007; Varagnoli 2009; Di Nucci 2009] fornendo importanti indicazioni per la conservazione e il recupero di tale patrimonio. Ė proprio dall'analisi critica di questi studi e dall'osservazione diretta delle peculiarità dei borghi che deriva la necessità di predisporre l'ontologia che si sta implementando.

Un approccio olistico e multidisciplinare (fig. 2) è stato adottato nella fase di analisi del sistema, al fine di avere una visione complessiva e integrata del patrimonio da studiare e per supportare l'organizzazione, secondo forme logiche e gerarchiche, e l'interoperabilità delle informazioni, grazie agli strumenti del rilievo e del web-semantico [Fiorani 20 I7]. 
Gli studi di architetti, ingegneri e archeologi sul patrimonio costruito abruzzese identificano diverse peculiarità insediative, caratterizzate in base alle tecniche e ai materiali [Redi 2003; Zordan et al. 2002], che ricorrono allinterno del tessuto edilizio dei borghi. Tra le tipologie edilizie maggiormente rappresentative, perfettamente integrate con il paesaggio, si trovano la casa monofamiliare, la casa-torre, la casa-mura e la casa a schiera (fig. 3) [Caravaggio, Meda 2004; Bartolomucci, Donatelli 20 I2]. Le strutture verticali sono realizzate con elementi in pietra posti in opera con tecniche differenti spesso risultato del sapere empirico (fig. 4). La ripartizione orizzontale degli edifici è affidata a volte, in pietra o laterizio, e a orizzontamenti lignei, a semplice o doppia orditura (fig. 5).

L'edilizia che caratterizza i centri dell'Appennino è da analizzare inoltre in relazione ad aspetti geomorfologici che, oltre ad aver influenzato la tipologia insediativa e la scelta dei materiali, condiziona la loro conservazione e tutela. A tal proposito diventa indispensabile organizzare i dati e integrarli in mappe del rischio come si evidenzia dal confronto con altri gruppi di ricerca [Acierno, Fiorani 20 I9]. II sistema informativo, strutturato secondo l'ontologia e l'integrazione con la rappresentazione tridimensionale, mostra potenzialità anche nel campo del monitoraggio favorendo la gestione del patrimonio architettonico in base ai fenomeni di dissesto ai quali i centri storici dell'Appennino sono costantemente soggetti. La definizione di un sistema digitale impiegato e ottimizzato alla scala del borgo rappresenta l'innesco di procedure di gestione e protezione del costruito storico e paesaggistico.

\section{Primi risultati e prospettive future}

I risultati della lettura critica del materiale edito e dall'analisi autoptica del costruito hanno consentito di definire la gerarchia alla base dell'organizzazione delle informazioni interne all'ontologia (fig. 6). Le caratteristiche dei centri analizzati impongono la necessità di identificare i complessi architettonici (CA) che definiscono il tessuto urbano e che consentono di comprendere i rapporti spaziali e funzionali tra i singoli manufatti. Coerentemente con

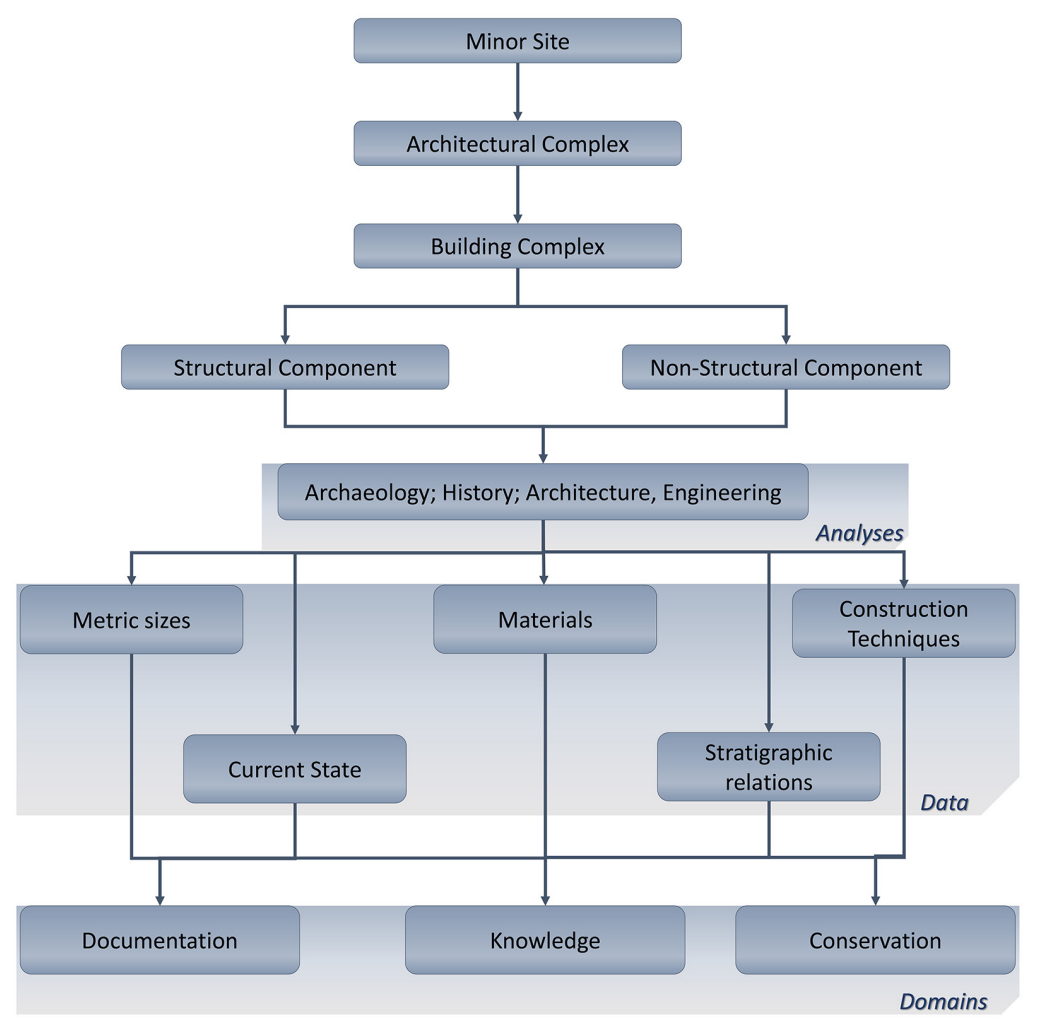


quanto riportato dalle raccomandazioni condivise a livello nazionale per la valutazione del patrimonio tutelato, ogni CA è "costituito dall'aggregazione di più corpi di fabbrica e definito spazialmente dalle strade che lo circoscrivono" [Raccomandazioni PCM p. 2I] e pertanto è fondamentale identificare i corpi di fabbrica (CF) che formano entità spaziali circoscritte del tessuto urbano. I CF vengono, invece, definiti a partire dall'analisi formale dei prospetti visibili e dall'articolazione plano-altimetrica, correlando quindi le osservazioni storico-archeologiche con quelle architettoniche e strutturali.

La corretta identificazione dei CF consente la scomposizione dell'edificio nelle sue componenti portanti e portate, owero nelle parti che caratterizzano l'ossatura dell'edificio e quelle che invece rappresentano i carichi gravanti sulle strutture, gli elementi di finitura e gli elementi di pregio, che a loro volta possono essere scomposti in ulteriori classi e secondo i medesimi criteri [Marra, Trizio, Fabbrocino in corso di stampa]. Questa scomposizione è ulteriormente implementata con l'approccio archeologico all'analisi delle murature [Brogiolo, Cagnana 20 I2] che permette di definire, per ogni struttura verticale, le Unità Stratigrafiche Murarie (USM) (fig. 7). In questo modo è possibile descrivere ogni singolo elemento analizzato rispetto agli aspetti archeologici, storici, architettonici, e strutturali, relazionandoli opportunamente ai tre domini identificati: Documentazione, Conoscenza, Conservazione. L'integrazione dei differenti linguaggi dell'analisi multidisciplinare consente di riconoscere la morfologia, la tipologia, le tecniche costruttive e i materiali adottati per la realizzazione dei manufatti, analogamente all'analisi delle informazioni derivanti dall'indagine storica e strutturale, che consente di valutare lo stato di fatto del bene, di evidenziare la presenza di forme
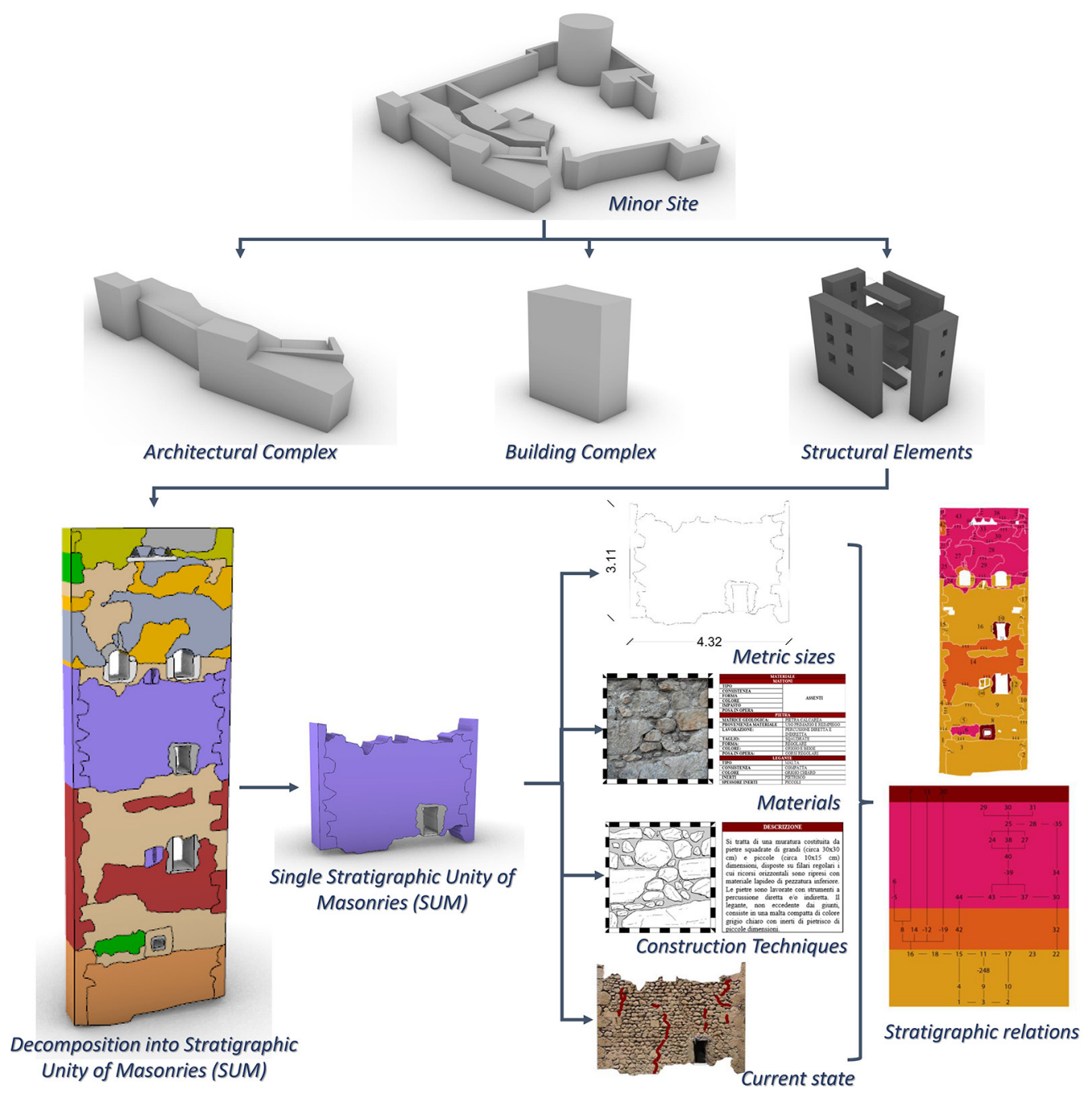
di degrado/dissesto e di comprendere le possibili cause che hanno innescato tali fenomeni. Infine, dall'osservazione diretta del manufatto e il ricorso agli strumenti innovativi disponibili nell'ambito del rilievo (geoslam, laser scanner, fotogrammetria aerea e terrestre) è possibile definire i rapporti dimensionali e quelli stratigrafici delle diverse parti costituenti i CF, favorendo la comprensione della storia evolutiva che discende dalla corretta relazione di tutte queste informazioni.

L'elaborazione della gerarchia illustrata ha consentito di tradurre il processo di conoscenza e conservazione del costruito storico a partire dalle specificità dell'archeologia dell'architettura e di comprendere i domini e le entità che sono necessarie a strutturare l'ontologia per la documentazione, analisi e modellazione dei siti e centri storici minori.

Sebbene siano state già identificate le relazioni esistenti tra i domini e le diverse entità, un ulteriore sforzo dovrà essere compiuto per tradurre queste informazioni secondo lo standard del CIDOC-CRM e per correlarle alle ontologie già implementate per il patrimonio costruito e archeologico [Acierno et al. 20 17; Aloia et al. 20 17; Zalamea Patino, Van Orshoven, Steenberghen 20 I8; Garozzo et al. 20 I9; Veninata 2020; Cheng et al. 202 I], trasformandole in risorse utili a livello comunitario e interoperabili con i sistemi di gestione del patrimonio culturale.

\section{Crediti}

Crediti dell'articolo: sebbene il contributo sia stato concepito unitariamente dagli autori, si attribuiscono a llaria Trizio il paragrafo I, ad Andrea Ruggieri il paragrafo 2, Adriana Marra il paragrafo 3 e a Francesca Savini il paragrafo 4.

\section{Riferimenti bibliografici}

Acierno M., Cursi S., Simeone D., Fiorani D. (2017). Architectural heritage knowledge modelling: An ontology-based framework for conservation process. In Journal of Cultural Heritage, n. 24, pp. 124- 133.

Acierno M., Fiorani D. (2019). Innovative Tools for Managing Historical Buildings: The Use of Geographic Information System and Ontologies for Historical Centers. In Int. Arch. Photogramm. Remote Sens. Spatial Inf. Sci., n. XLII-2/WI I, pp. 2 I-27.

Aloia N. et al. (2017). Mapping the ARIADNE Catalogue Data Model to CIDOC CRM: Bridging Resource Discovery and Item-Level Access. In SCIRES-IT, n. 7(I), pp. I-8.

ArCo (2020). <http://wit.istc.cnrit/arco> (consultato il 25 febbraio 2021).

Bannour I. et al. (20I8). CRMCR - a CIDOC-CRM extension for supporting semantic interoperability in the conservation and restoration domain. In 2018 3rd Digital Heritage International Congress (DigitalHERITAGE) Held Jointly with 2018 24th International Conference on Virtual Systems \& Multimedia (VSMM 20 I 8), pp. I-8.

Bartolomucci C., Donatelli A. (20 I 2). La conservazione nei centri storici minori abruzzesi colpiti dal sisma del 2009: esigenze di riuso e questioni di conservazione. In G. Biscontin, G. Driussi (a cura di). La conservazione del patrimonio architettonico all'aperto: superfici, strutture, finiture, contesti, pp. I0 I- I I I. Marghera-Venezia: Arcadia Ricerche.

Bonamico S., Tamburini G. (a cura di) (1996). Centri antichi minori d'Abruzzo. Recupero e valorizzazione. Roma: Gangemi Editore. Brogiolo G. P., Cagnana A (20 I2). Archeologia dell'architettura. Metodi e interpretazioni. Firenze: All'Insegna del Giglio.

Brusaporci S. (2007). Le murature nell'architettura del versante meridionale del Gran Sasso (secc. XI-XIV). Roma: Gangemi Editore. Brusaporci S. (Ed.) (20I5). Handbook of Research on Emerging Digital Tools for Architectural Surveying, Modeling, and Representation. Hershey: IGI Global.

Caravaggio P., Meda A. (2004). Manuale del recupero di Castel del Monte. Roma: DEl.

Cheng Y-M., Kuo C-L., Mou C-C. (202I). Ontology-based HBIM for historic buildings with traditional woodwork in Taiwan. In Journal of Civil Engineering and Management, n. 27(I), pp. 27-44.

Di Nucci A. (2009). L' arte di costruire in Abruzzo. Tecniche murarie nel territorio della Diocesi di Valva e Sulmona. Roma: Gangemi Editore.

Doerr M. et al. (2020). Volume A: Definition of the CIDOC Conceptual Reference Model. <http://www.cidoc-crm.org/sites/ default/files/CIDOC CRM_v6.2.9 30-4-2020.pdf> (consultato il 21 gennaio 2021).

Dore C., Murphy M. (20I5). Historic Building Information Modelling (HBIM). In S. Brusaporci (Ed.). Handbook of Research on Emerging Digital Tools for Architectural Surveying, Modeling, and Representation, pp. 233-273. Hershey: IGl Global.

Fiorani D. (2017). La modellazione della conoscenza nel restauro: uno sviluppo per il BHIMM. Problematiche generali e il caso-studio di San Saba in Roma. In S. Della Torre (Ed.). Built Heritage Information Modelling/Management BHIMM. Cham: Springer. 
Garozzo R. et al. (2017). CulTO: an ontology-based annotation tool for data curation in cultural heritage. In Int. Arch. Photogramm. Remote Sens. Spatial Inf. Sci., n. XLII-2M5, pp. 267-274.

Lo Turco M., Calvano M., Giovannini E. C. (2019). Data Modeling for Museum Collections. In Int. Arch. Photogramm. Remote Sens. Spatial Inf. Sci, n. XLII-2/W9, pp. 433-440.

Lorhard J. ( 1606). Ogdoas Scholastica continens diagraphen typicam artium Grammatices, Logices, Rhetorices. Sangalli: Georgium Straub. <https://books.google.it/books?id=Elvcl kak6xEC\&printsec=frontcover\&hl=it\&source=gbs_ge_summary_r\&cad=0\#$\mathrm{v}=$ onepage\&q\&f=false> (consultato il $2 \mathrm{l}$ gennaio 202 I).

Marra A. et al. (2019). On a Rational and Interdisciplinary Framework for the Safety and Conservation of Historical Centres in Abruzzo Region. In International Journal of Architectural Heritage, n. I 5(4), pp. 608-626.

Marra A., Trizio I., Fabbrocino G. (in corso di stampa). Digital Tools for the knowledge and safeguard of historical heritage. In Proceedings of 8th Civil Structural Health Monitoring Workshop (CSHM-8).

Messaoudi T. et al. (20।8). An ontological model for the reality-based 3D annotation of heritage building conservation state. In Journal of Cultural Heritage, n. 29, pp. 100-1 12.

Novak-Marcincin J., Gîf, D., Nicolesc, A. (2014). The standard of axes in ontology of communication. In International Letters of Social and Humanistic Sciences, n. 4I, pp. 176-183.

Noy, N. F., McGuinness D. L. (200 I). Ontology Development 101: A Guide to Creating Your First Ontology'. Stanford Knowledge Systems Laboratory Technical Report KSL-0I-05 and Stanford Medical Informatics Technical Report SMI-200 I-0880, March 200 I. <http://www.ksl.stanford.edu/people/dlm/papers/ontology-tutorial-noy-mcguinness-abstract.html> (consultato il 20 febbraio 2021).

Oreni D.et al. (20 I4). Survey turned into HBIM: the restoration and the work involved concerning the Basilica di Collemaggio after the earthquake (L'Aquila). In ISPRS Ann. Photogramm. Remote Sens. Spatial Inf. Sci., n. II-5, pp. 267-273.

Parisi P., Lo Turco M., Giovannini E.C. (2019). The value of knowledge through H-BIM models: historic documentation with a semantic approach. In ISPRS Annals of the Photogrammetry, Remote Sensing and Spatial Information Sciences, n. 42(2M9), pp. $58 \mid-588$.

Raccomandazioni PCM (201 I). Direttiva del Presidente del Consiglio dei Ministri, 09/02/20 I I. Linee guida per la valutazione e riduzione del rischio sismico del patrimonio culturale - allineamento alle nuove Norme tecniche per le costruzioni. Roma: G.U. n. 47 del 26 febbraio 201 I - Suppl. Ordinario n. 54.

Redi F. (2003). Materiali, tecniche e cantieri: primi dati dal territorio aquilano. In P. Peduto, R. Fiorillo (a cura di). Atti del III Congresso Nazionale di Archeologia Medievale. Castello di Salerno, Santa Sofia, 2-5 ottobre 2003, pp. 587-593. Firenze: All'Insegna del Giglio.

Savini F., Fabbrocino G., Marra A. (202I). Digitization of Historical Architectural Elements, a Workflow for Knowledge of Minor Centers in Inner Areas. In DisegnarecCon, 26, pp. 9. I-9.15.

Trizio I. et al. (2020). The archaeological park of Navelli (Italy) in the reconstruction plan: Hypothesis of adaptive Reuse. In Int Arch. Photogramm. Remote Sens. Spatial Inf. Sci., n. XLIV -M-I-2020, pp. 929-936.

Varagnoli C. (2009). Muri parlanti. Prospettive per l'analisi e la conservazione dell'edilizia storica. Firenze: Alinea editrice.

Veninata C. (2020). Dal Catalogo generale dei beni culturali al knowledge graph del patrimonio culturale italiano: il progetto ArCo. In Digltalia, n. 2, pp. 43-56.

Zalamea Patino O. P., Van Orshoven J., Steenberghen T. (2018). Merging and expanding existing ontologies to cover the Built Cultural Heritage domain. In Journal of Cultural Heritage Management and Sustainable Development, n. 8(2), pp. I62-I78.

Zordan L. et al. (2002). Le tradizioni del costruire della casa in pietra: materiali, tecniche, modelli e sperimentazioni. L'Aquila: Università degli Studi dell'Aquila, Dipartimento di Architettura e Urbanistica.

\section{Autori}

Ilaria Trizio, Istituto per le Tecnologie della Costruzione, CNR L'Aquila (AQ), ilaria.trizio@itc.cnr.it Adriana Marra, Istituto per le Tecnologie della Costruzione, CNR L'Aquila (AQ), marra@itc.cnr.it: Francesca Savini, Istituto per le Tecnologie della Costruzione, CNR L'Aquila (AQ), savini@itc.cnr.it Andrea Ruggieri, Università degli Studi del Molise, a.ruggieri3@studenti.unimol.it

Per citare questo capitolo:Trizio Ilaria, Marra Adriana, Savini Francesca, Ruggieri Andrea. (2021). L'architettura vernacolare e i suoi linguaggi: verso un'ontologia dei centri storici minori/The vernacular architecture and its languages: towards an ontology of the minor historic centres. In Arena A., Arena M. Mediati D. Raffa P. (a cura di). Connettere. Un disegno per annodare e tessere. Linguaggi Distanze Tecnologie. Atti del $42^{\circ}$ Convegno Internazionale dei Docenti delle Discipline della Rappresentazione/Connecting. Drawing for weaving relationship. Languages Distances Technologies. Proceedings of the $42^{\text {th }}$ International Conference of Representation Disciplines Teachers. Milano: FrancoAngeli, pp. $1198-1215$. 


\title{
The Vernacular Architecture and its Languages: Towards an Ontology of the Minor Historic Centres
}

\author{
Ilaria Trizio \\ Adriana Marra \\ Francesca Savini \\ Andrea Ruggieri
}

Abstract

The multifaced nature of the historic centres is the result of heterogeneous aspects that reflect environmental and human circumstances, such as the orography of the terrain, the socio-economics conditions related to the historic period, the evolution of techniques and construction technologies starting from the empiric knowledge, the long-term use and the change of intended use of the settlements. This nature represents an added value, which characterizes and make historical centres unique, but it can be also an issue in the managing and the organization of the operations aimed at their conservation. It is known that to protect the heritage, whether it be an individual object or a complex organism such as a hamlet, it is necessary to start from the knowledge and so from the data deriving from multidisciplinary analyses. Therefore, it is important to find some common ground that may lie in defining the systemic architecture and standardizing the data acquisition. The research discussed is aimed at studying historic centres at different scales, considering their deconstruction in single buildings, architectural complexes, historic centre, homogeneous territorial areas, and finally, distant centres matched by common characteristics.

Keywords

ontology, minor historical centres, architectural languages, built heritage, local constructive techniques.

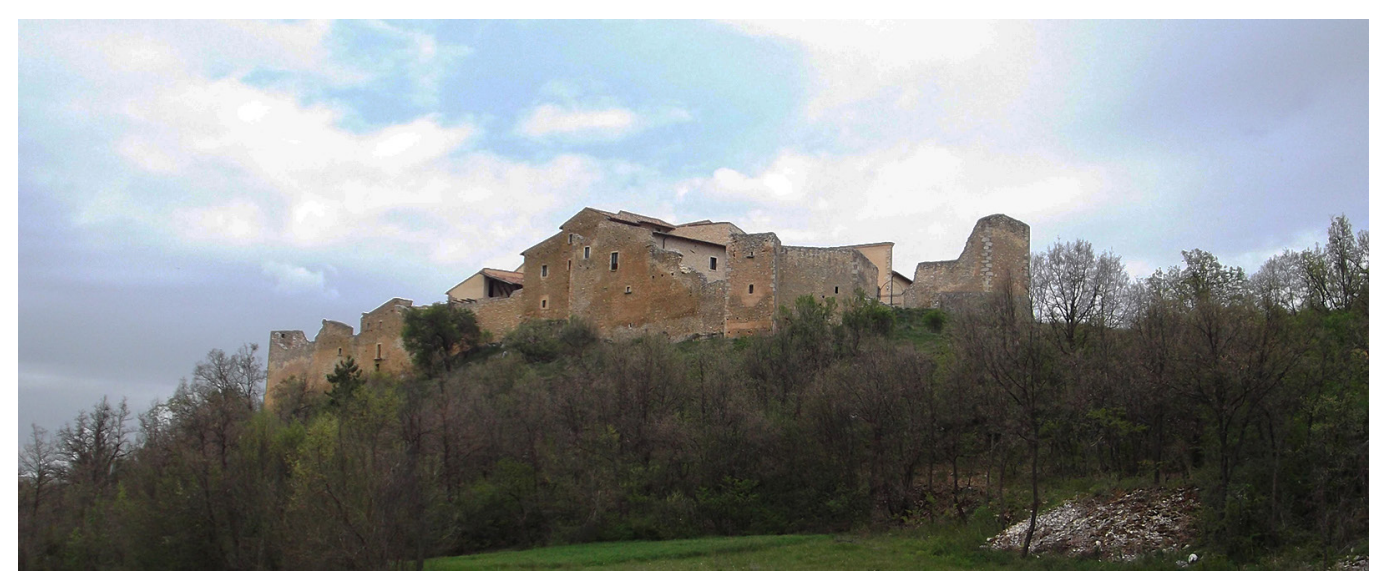




\section{Introduction}

In the processes of conservation of the built heritage, the main action is represented from the knowledge of its morphological and formal aspects that require particular attention when operating on the territorial scale, such as for the minor historical centres located in the national inner areas. Within this framework, the knowledge is not to be intended as the mere acquisition of information but as a multidisciplinary and dynamic process, wherein the actors involved collaborate to acquire, integrate and analyse the data necessary to reconstruct the evolutive history of the artefact and the territorial context in which they are set in. To ensure the conservation of such heritage is necessary a constant update of the data acquired during the knowledge and documentation phase, on the one hand, and the identification of a common language through which share and implement the different information, on the other. This effort is aimed to properly structuring the data architecture and to guarantee the interoperability and the wide range spreading of the acquired knowledge. Moreover, the constant evolution of the digital technologies applied to the heritage highlighted the benefits deriving from the parametric modelling of the built heritage in the managing and the data exchange in a single three-dimensional model [Oreni et al. 2014; Dore, Murphy 20 I5; Brusaporci 20 I 5]. At the same time, the potential of the semantic web, through the creation of specifics ontologies allowing to hierarchically organize the information as to exhaustively describing the historic artefacts and its associated processes, is being explored to properly represent the informative asset of the multidisciplinary analyses [Acierno et al. 2017; Garozzo et al. 2017; Lo Turco et al. 2019].

Starting from these assumptions, the paper outlines the preliminary results of a research study aimed at defining an ontology able to document the built heritage characterizing the minor historical centres in Abruzzo, [Trizio et al. 2020; Marra et al. 20 I 9;Savini, Fabbrocino, Marra 202I], analysing it from different perspectives, from the archaeological to the urbanistic, passing through the architectural one. The goal of the research study is to define a methodology ontology-based able to facilitate the documentation, knowledge, and conservation processes of the built heritage in minor historic centres, which can be extended to other domains and easily integrated into BIM systems. In a later phase, it is planned the integration of the structured data within a digital environment able to connect the HBIM models to the GIS for the multi-scalar managing of the historic centres, promoting not only their knowledge but also the monitoring and the assessment of the risk to which they are particularly exposed.

Fig. I. Constructive peculiarities of Abruzzo's minor historical centres: the village of Navelli (AQ), top; the village of Castelvecchio Calvisio (AQ), bottom (photo by (AQ), botton

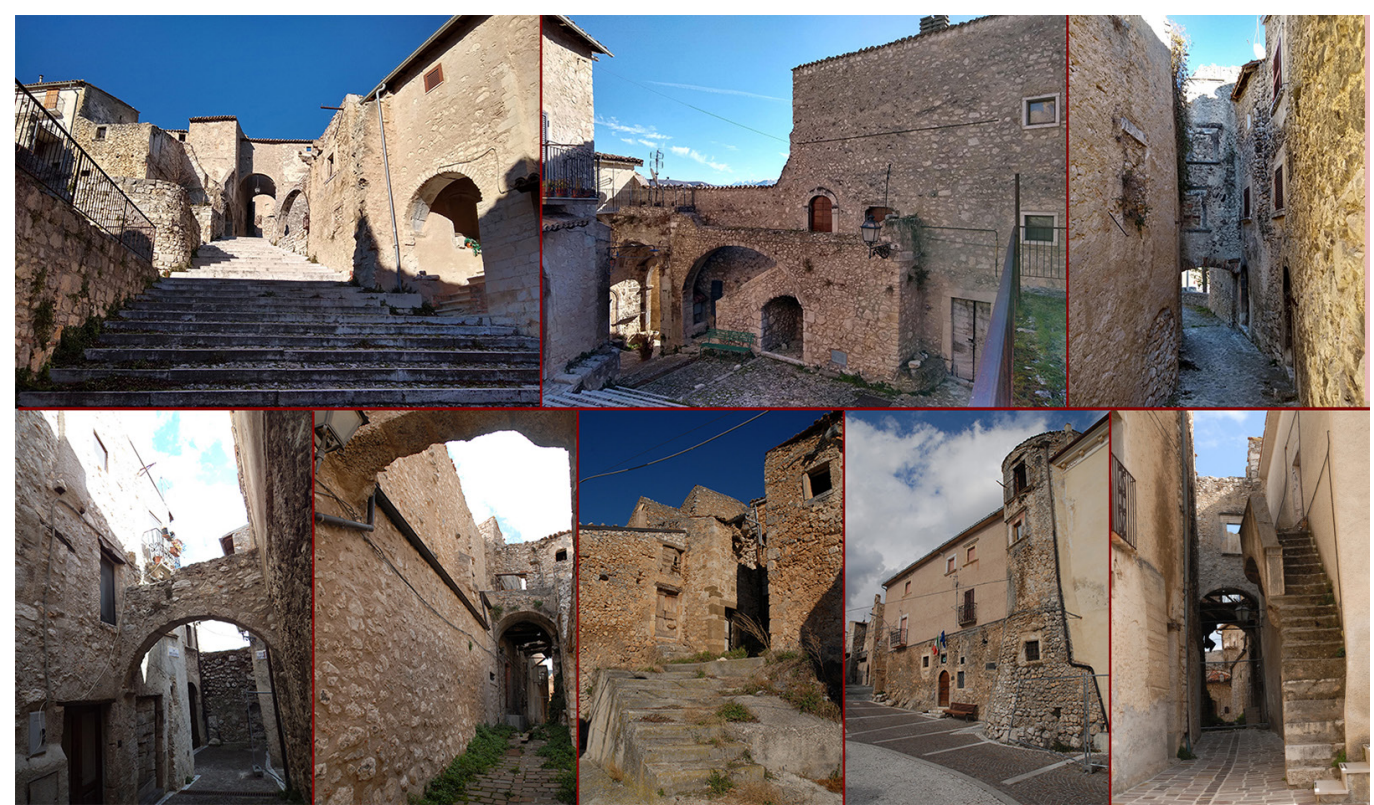


Fig. 2. Flowchart for the development of minor centres ontology (elaboration by authors)

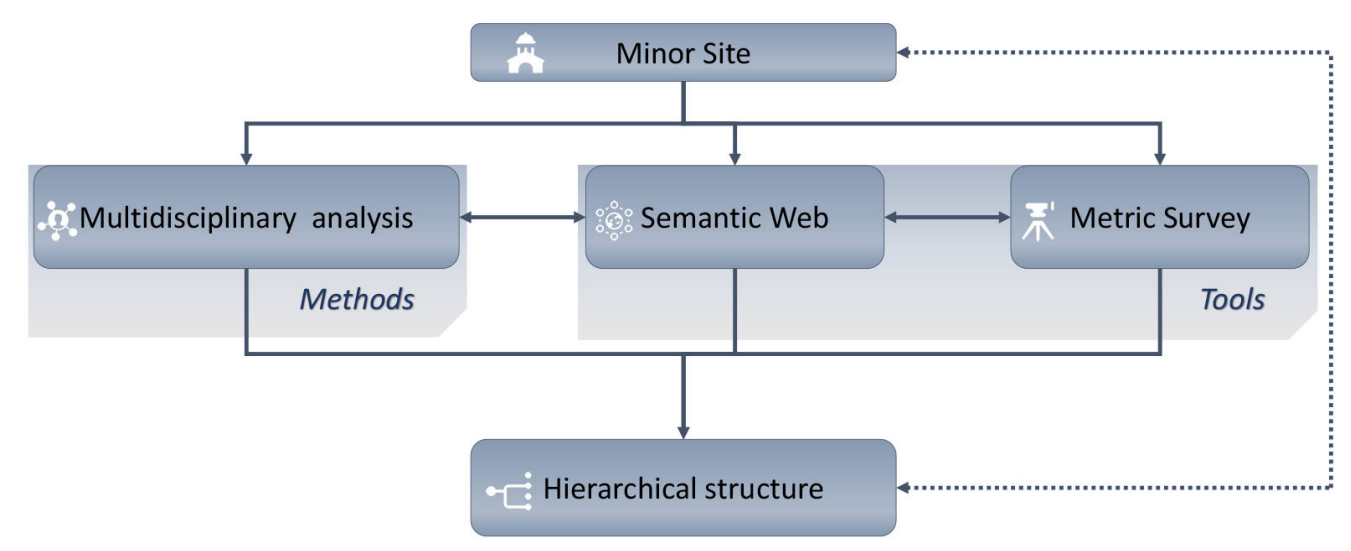

\section{Ontologies for the built heritage}

The possibilities offered by the ICT in the heritage conservation domain are several, and direct consequence of its applications is the acquisition, analysis, and restitution of a huge amount of heterogeneous data, often not integrated and inaccessible, which usage can be optimized by choosing a semantic approach taking advantage of the tool offered by the semantic web. In particular, ontologies became widely used. The word 'ontology' itself is capable of quite many meanings, as is borrowed from the field of philosophy as "the study of being as being" [Lorhard, 1606]. The declination of this concept in the Artificial Intelligence domain led us to the definition of ontology as "a formal explicit description of concepts in a domain of discourse (classes), properties of each concept describing various features and attributes of the concept (slots), and restrictions on slots (facets)" [Novak-Marcincin, Gifu, Nicolescu 20|4, p. 176].

The reference ontology in the $\mathrm{HC}$ field is the CIDOC-CRM as Conceptual Reference Model, defined in its latest release (7.0.I) as "a formal ontology intended to facilitate the integration, mediation and interchange of heterogeneous cultural heritage information" [Doerr et al. 2020, p. i]. As the CIDOC-CRM aims to catalogue the documentation regarding the cultural heritage, in the scientific community arose the need of extending and characterize it depending on the specificities and the intrinsic issues case-by-case recognized and so faced. Descending more specifically in the built heritage field, there are many applications in literature developed in the HBIM environment about an ontology-based approach capable
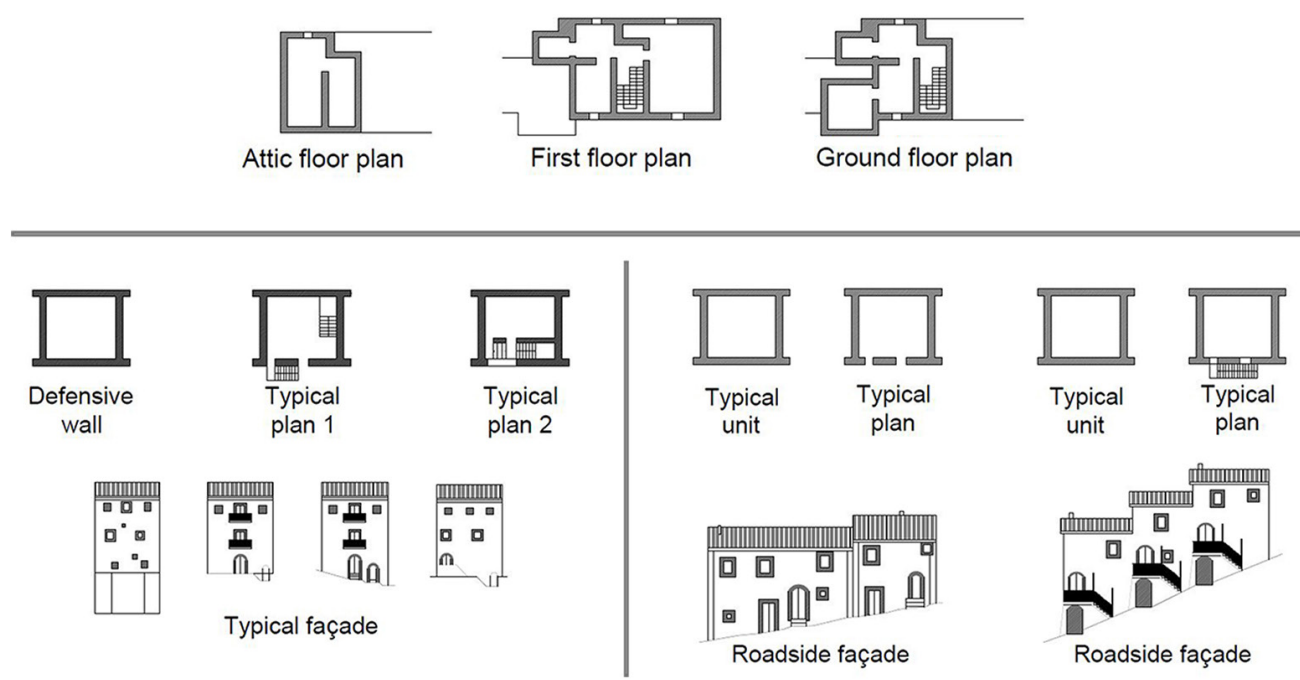

Fig. 3. Building types
identify in Abruzzo's minor historical centres: single house or towerhouse, top; fortress houses, bottom left; right (adapted from Caravaggio, Meda 2004 pp. 33-35). 
to radically change the modelling process, having a certain impact on the quality of the informative content.

Regarding the conservation's topics, has been proposed a prototype [Acierno et al. 20 I7], which introduces four main knowledge domains (artefact - lifecycle - architectural heritage investigation process - actors), then connected with the BIM environment providing an effective integration between the ontology and the HBIM model. The proposed model highlights the need to consider when dealing with ancient architecture its hermeneutical dimension, so in this direction moves the (O)BHIMM approach considering each building component in its concrete dimension [Fiorani 20 I7]. Further application of the ontological process in the parametric environment involves the direct connection of the knowledge base into the Revit families, ensuring a common and interoperable language through a semantic way [Parisi, Lo Turco, Giovannini 2019].

A formal extension of the CIDOC-CRM specifically related to the conservation and restoration of the cultural object is the CRM ${ }_{C R}$ [Bannour et al. 20I8], an ontological model that aims to describe a cultural object through its basic characteristics, such as identifica-

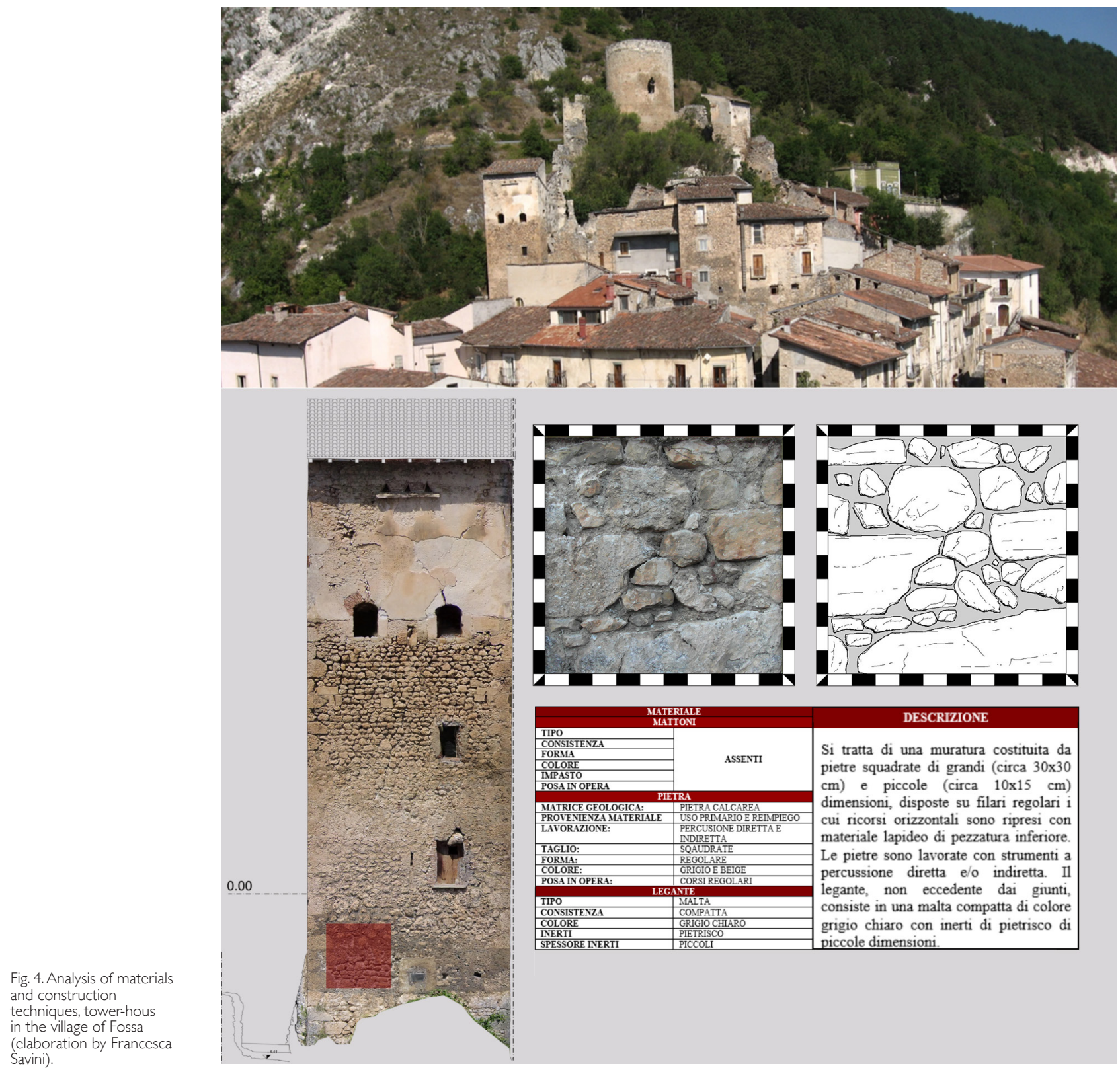


tion, physical features, and localization in a specific context. In particular, about the correlation between the semantic content and the spatial-morphological dimension of the built heritage, an integration procedure is proposed using an ontological model for recording multidisciplinary observations of the conservation state in direction of a 'semantic-aware' three-dimensional representation [Messaoudi et al. 20 18], in order to spatially allocate the data stored in the ontology.

A further need is the spreading and the wide range uptake of the ontologies created for the cultural heritage, and to that extent has been implemented platforms and software [ArCo 2020; Garozzi et al. 2019], promoting the cooperation among different institutions and figures and increasing quantity and quality of the information for a better fruition of the heritage.

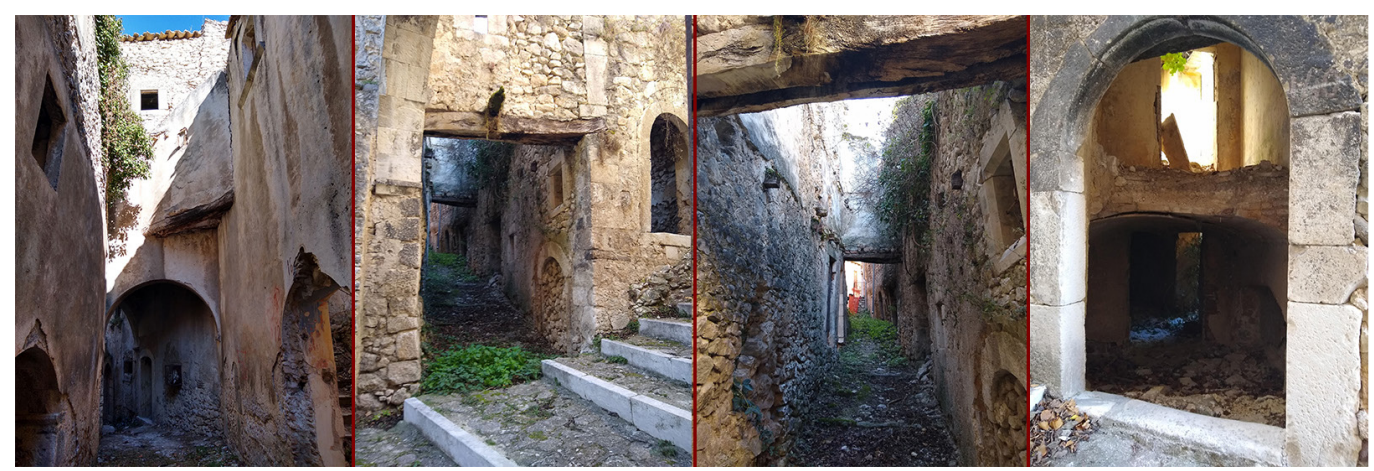

\section{Peculiar features of the minor historic centres: from the language analysis to the design of a dedicated ontology}

The research study, which is being carried out on historic centres with cases of study in the inner areas of Abruzzo and Molise, is aimed at defining knowledge tools developed through the integration of languages and methods. These tools, detected in the informative systems, are geared to support local administrations in defining operative strategies and selecting interventions of use/fruition and conservation. Such need, combined with that of organizing the research study regarding the multiscale analysis, originated the development of a methodology ontology-based of which some preliminary results are here discussed.

The Abruzzo territory stands out for the widespread presence of small aggregates characterized by 'poor' construction, perfectly integrated with the landscape and environmental context, that acquired over time historical and cultural values (fig. I) and unfortunately affected by phenomena related to the depopulation and the reoccurring seismic events [Varagnoli et al. 2020]. Several studies analysed the construction typologies as the constructive traditional techniques of the Abruzzo's architecture [Bonamico, Tamburini 1996; Zordan et al. 2002; Caravaggio, Meda 2004; Brusaporci 2007; Varagnoli 2009; Di Nucci 2009] providing important suggestions about the conservation and recovery of such heritage. It is from the critical analysis of these research studies and the direct observation of the peculiarities of the hamlets that arise the need to arrange the ontology proposed.

A holistic and multidisciplinary approach (fig. 2) has been adopted in the system's analysis phase, aiming to an overall and integrated view of the heritage to be studied and supporting the organization, through logic and hierarchical forms, and the information interoperability, thanks to survey and semantic web tools [Fiorani 2017].

The analyses of architects, engineers and archaeologists on the built heritage in Abruzzo point out several settlements' peculiarities characterized according to the techniques and 
the materials [Redi 2003; Zordan et al. 2002], recurring in the built fabric of the hamlets. Amongst the building types most representative, perfectly integrated with the landscape, there are the one-family house, the tower-house, the fortress-house, and the terraced house (fig. 3) [Caravaggio, Meda 2004; Bartolomucci, Donatelli 20 I2]. The vertical structures are realized with stone elements placed using different techniques, often resulting from empiric knowledge (fig. 4). The horizontal division was entrusted to vaults, stone-built or bricks-built, and wooden floors, with simples or double roof frame (fig. 5).

The typical buildings of the Apennine's centres have to be further analysed regarding geomorphological aspects that, besides having influenced the settlement typology and the materials' selection, affect their conservation and protection. In that regard becomes crucial to organize data integrating them into risk maps as highlighted by the comparison with other research groups [Acierno, Fiorani 2019]. The informative system, structured according to the ontology and the integration with the three-dimensional representation, shows potential also in the monitoring field, encouraging the managing of the built heritage in accordance with instability phenomena constantly affecting the Apennine's historical centres. The definition of a digital system used and optimized at the hamlet's scale represents the trigger of procedures to manage and protect the built heritage and the landscape.

\section{First results and future prospects}

The results of the critical analysis of the published studies and the autoptic analysis of the built ensured the definition of the hierarchy underlying the organization of the information into the ontology (fig. 6). The characteristics of the centres analysed demands the identification of the architectural complex (CA) defining the urban fabric and allowing to understand the spatial and functional relations amongst the single artefacts. According to national recommendations shared at the national level for the assessment of the protected heritage, each CA is "constituted by the aggregation of several buildings and spatially defined by the

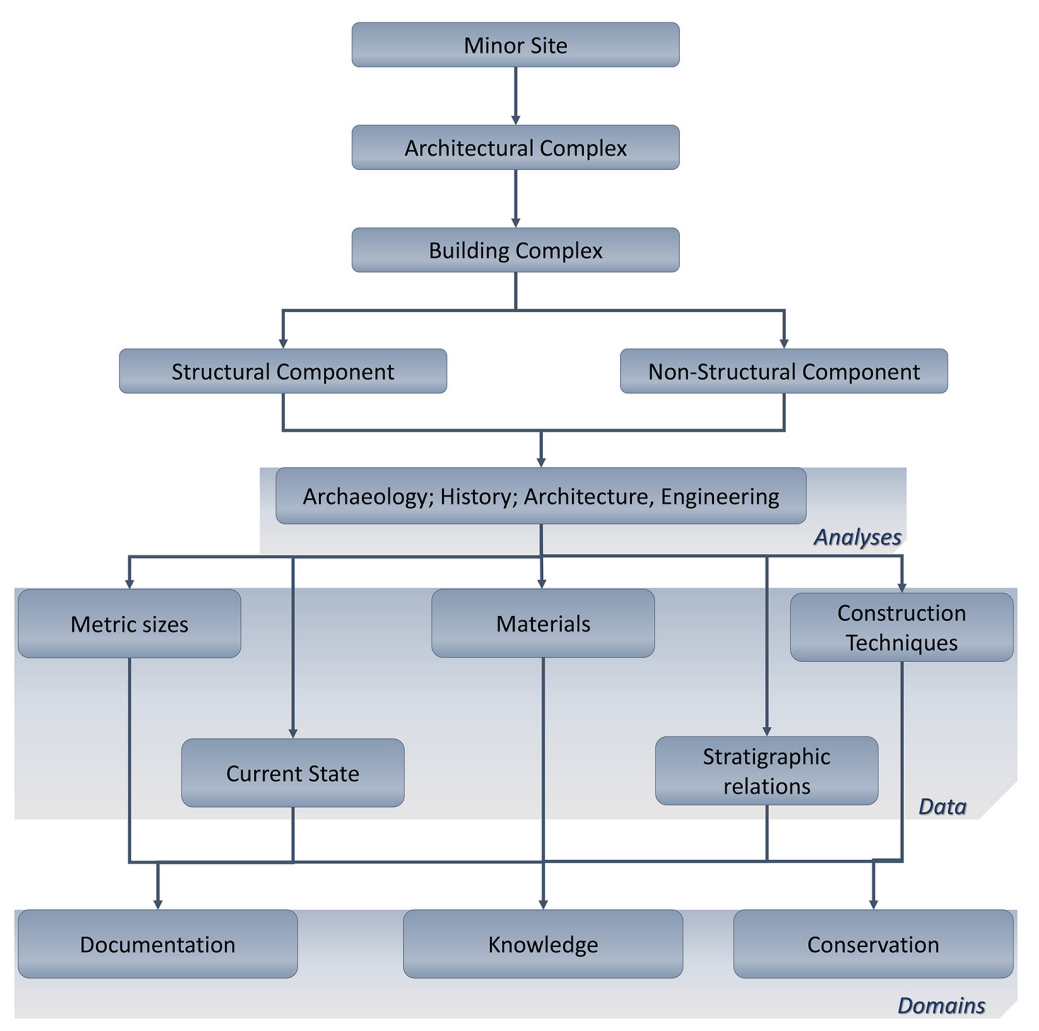


roads delimiting it" [PCM Recommendations p. 2I] and becomes so crucial to identify the building units (CF) forming confined spatial entities of the urban fabric. Instead, the CFs are defined from the formal analysis of the visible elevations and the plane-altimetric structure, correlating so the historic-archaeological evaluations with the architectural and structural ones.

The correct CF identification ensures the decomposition of the building in its structural and non-structural components, namely in the parts characterizing the building's backbone and the ones representing instead the loads on the structure, the finishes and the valuable elements, which can be decomposed in further classes according to the same criteria [Marra, Trizio, Fabbrocino in press]. This decomposition is furtherly improved with the archaeological approach at the masonries analysis [Brogiolo, Cagnana 2012] thanks to which it is possible to identify the Stratigraphic Unity of Masonries (SUM) for each vertical structure (fig. 7). In such a way, it is possible to describe each element analysed with regard to the archaeological, historical, architectural and structural aspects, properly relating them to the three identified domains: Documentation, Knowledge, Conservation.

The integration of the different languages of the multidisciplinary analysis supports the identification of morphology, typology, construction technique and the materials used for the artefact, at the same time the information derived from the historical and structural analyses enables the assessment of the current condition of heritage, highlighting the presence of degradation/damage forms and understanding the possible causes triggering such

Fig. 7. Inphographics of the information hierarchy (elaboration by Adriana Marra and Francesc Savini).
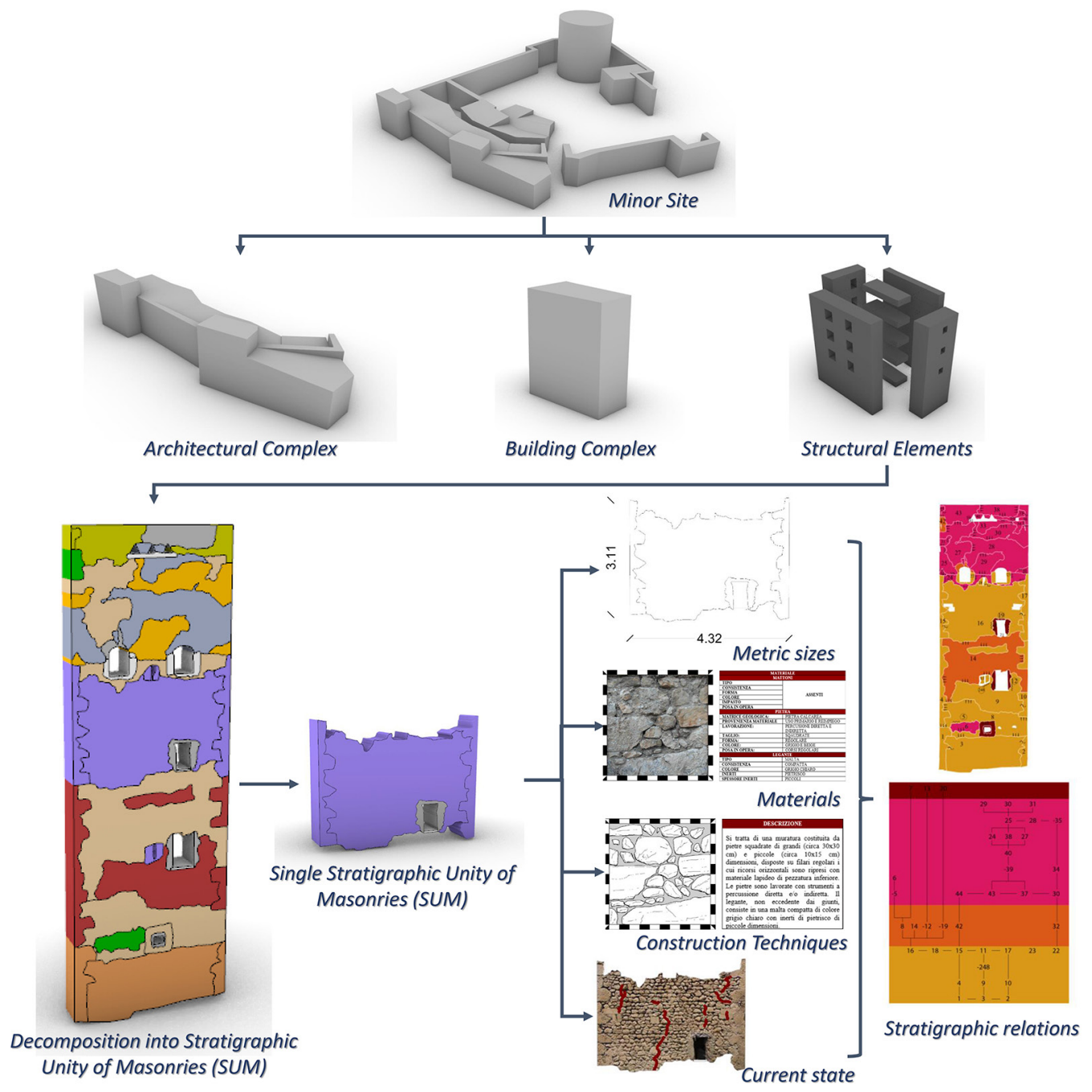
phenomena. Finally, through the direct observation of the artefact and the use of innovative tools in the field of the architectural survey (geoslam, laser scanner, aerial and terrestrial photogrammetry) is possible to define the dimensional and stratigraphic relationships of the different parts forming the $\mathrm{CF}$, favouring the understanding of the evolutive history deriving from the proper correlation of that information.

The elaboration of the illustrated hierarchy has allowed to translate the process of knowledge and conservation of the built heritage starting from the specificity of the archaeology of architecture and to understand the domains and the entities needed for structuring the ontology for the documentation, analysis and modelling of the sites and the minor historic centres.

Althought the existing relationships between the domains and the different entities has been already identified, a further effort has to be performed to translate this information according to the CIDOC-CRM standard and to correlate it to the ontology already implemented for the built and archaeological heritage [Acierno et al. 20 I7; Aloia et al. 20 I7; Zalamea Patino,Van Orshoven, Steenberghen 201 8; Garozzo et al. 20 I9; Veninata 2020; Cheng et al. 202 I]. In such a way, the information ontology-based can become useful resources at

\section{Credits}

Although the paper is the result of the authors' collective work, llaria Trizio wrote section I, Andrea Ruggieri wrote the section 2, Adriana Marra wrote the section 3 and Francesca Savini wrote the section 4.

\section{References}

Acierno M., Cursi S., Simeone D., Fiorani D. (2017). Architectural heritage knowledge modelling: An ontology-based framework for conservation process. In Journal of Cultural Heritage, n. 24, pp. 124- 133.

Acierno M., Fiorani D. (2019). Innovative Tools for Managing Historical Buildings: The Use of Geographic Information System and Ontologies for Historical Centers. In Int. Arch. Photogramm. Remote Sens. Spatial Inf. Sci., n. XLII-2/WI I, pp. 2 I-27.

Aloia N. et al. Mapping the ARIADNE Catalogue Data Model to CIDOC CRM: Bridging Resource Discovery and Item-Level Access. In SCIRES-IT, n. 7(I), pp. I-8.

ArCo (2020). <http://wit.istc.cnr.it/arco> (accessed 2021, February 25).

Bannour I. et al. (20I8). CRMCR - a CIDOC-CRM extension for supporting semantic interoperability in the conservation and restoration domain. In 2018 3rd Digital Heritage International Congress (DigitalHERITAGE) Held Jointly with 2018 24th International Conference on Virtual Systems \& Multimedia (VSMM 20 I 8), pp. I-8.

Bartolomucci C., Donatelli A. (20 I 2). La conservazione nei centri storici minori abruzzesi colpiti dal sisma del 2009: esigenze di riuso e questioni di conservazione. In G. Biscontin, G. Driussi (a cura di). La conservazione del patrimonio architettonico all'aperto: superfici, strutture, finiture, contesti, pp. I0 I- I I I. Marghera-Venezia: Arcadia Ricerche.

Bonamico S., Tamburini G. (a cura di) (1996). Centri antichi minori d'Abruzzo. Recupero e valorizzazione. Roma: Gangemi Editore. Brogiolo G. P., Cagnana A (20 I2). Archeologia dell'architettura. Metodi e interpretazioni. Firenze: All'Insegna del Giglio.

Brusaporci S. (2007). Le murature nell'architettura del versante meridionale del Gran Sasso (secc. XI-XIV). Roma: Gangemi Editore. Brusaporci S. (Ed.) (20I5). Handbook of Research on Emerging Digital Tools for Architectural Surveying, Modeling, and Representation. Hershey: IGI Global.

Caravaggio P., Meda A. (2004). Manuale del recupero di Castel del Monte. Roma: DEl.

Cheng Y-M., Kuo C-L., Mou C-C. (202I). Ontology-based HBIM for historic buildings with traditional woodwork in Taiwan. In Journal of Civil Engineering and Management, n. 27(I), pp. 27-44.

Di Nucci A. (2009). L' arte di costruire in Abruzzo. Tecniche murarie nel territorio della Diocesi di Valva e Sulmona. Roma: Gangemi Editore.

Doerr M. et al. (2020). Volume A: Definition of the CIDOC Conceptual Reference Model. <http://www.cidoc-crm.org/sites/ default/files/CIDOC CRM_v6.2.9 30-4-2020 .pdf> (accessed 2021, January 21).

Dore C., Murphy M. (20I5). Historic Building Information Modelling (HBIM). In S. Brusaporci (Ed.). Handbook of Research on Emerging Digital Tools for Architectural Surveying, Modeling, and Representation, pp. 233-273. Hershey: IGl Global.

Fiorani D. (2017). La modellazione della conoscenza nel restauro: uno sviluppo per il BHIMM. Problematiche generali e il caso-studio di San Saba in Roma. In S. Della Torre (Ed.). Built Heritage Information Modelling/Management BHIMM. Cham: Springer. 
Garozzo R. et al. (2017). CulTO: an ontology-based annotation tool for data curation in cultural heritage. In Int. Arch. Photogramm. Remote Sens. Spatial Inf. Sci., n. XLII-2M5, pp. 267-274.

Lo Turco M., Calvano M., Giovannini E. C. (2019). Data Modeling for Museum Collections. In Int. Arch. Photogramm. Remote Sens. Spatial Inf. Sci, n. XLII-2/W9, pp. 433-440.

Lorhard J. ( 1606). Ogdoas Scholastica continens diagraphen typicam artium Grammatices, Logices, Rhetorices. Sangalli: Georgium Straub. <https://books.google.it/books?id=Elvcl kak6xEC\&printsec=frontcover\&hl=it\&source=gbs_ge_summary_r\&cad=0\#$\mathrm{v}=$ onepage\&q\&f=false $>$ (accessed $202 \mathrm{I}$, January $2 \mathrm{I}$ ).

Marra A. et al. (2019). On a Rational and Interdisciplinary Framework for the Safety and Conservation of Historical Centres in Abruzzo Region. In International Journal of Architectural Heritage, n. I 5(4), pp. 608-626.

Marra A., Trizio I., Fabbrocino G. (in corso di stampa). Digital Tools for the knowledge and safeguard of historical heritage. In Proceedings of 8th Civil Structural Health Monitoring Workshop (CSHM-8).

Messaoudi T. et al. (20।8). An ontological model for the reality-based 3D annotation of heritage building conservation state. In Journal of Cultural Heritage, n. 29, pp. 100-1 12.

Novak-Marcincin J., Gîf, D., Nicolesc, A. (2014). The standard of axes in ontology of communication. In International Letters of Social and Humanistic Sciences, n. 4 I, pp. 176-183.

Noy, N. F., McGuinness D. L. (200 I). Ontology Development 101: A Guide to Creating Your First Ontology'. Stanford Knowledge Systems Laboratory Technical Report KSL-0I-05 and Stanford Medical Informatics Technical Report SMI-200 I-0880, March 200 I <http://www.ksl.stanford.edu/people/dlm/papers/ontology-tutorial-noy-mcguinness-abstract.html> (accessed 202I, February 20).

Oreni D.et al. (20I4). Survey turned into HBIM: the restoration and the work involved concerning the Basilica di Collemaggio after the earthquake (L'Aquila). In ISPRS Ann. Photogramm. Remote Sens. Spatial Inf. Sci., n. II-5, pp. 267-273.

Parisi P., Lo Turco M., Giovannini E.C. (2019). The value of knowledge through H-BIM models: historic documentation with a semantic approach. In ISPRS Annals of the Photogrammetry, Remote Sensing and Spatial Information Sciences, n. 42(2M9), pp. $58 \mid-588$.

Raccomandazioni PCM (201 I). Direttiva del Presidente del Consiglio dei Ministri, 09/02/20 I I. Linee guida per la valutazione e riduzione del rischio sismico del patrimonio culturale - allineamento alle nuove Norme tecniche per le costruzioni. Roma: G.U. n. 47 del 26 febbraio 201 I - Suppl. Ordinario n. 54.

Redi F. (2003). Materiali, tecniche e cantieri: primi dati dal territorio aquilano. In P. Peduto, R. Fiorillo (a cura di). Atti del III Congresso Nazionale di Archeologia Medievale. Castello di Salerno, Santa Sofia, 2-5 ottobre 2003, pp. 587-593. Firenze: All'Insegna del Giglio.

Savini F., Fabbrocino G., Marra A. (202I). Digitization of Historical Architectural Elements, a Workflow for Knowledge of Minor Centers in Inner Areas. In DisegnarecCon, 26.

Trizio I. et al. (2020). The archaeological park of Navelli (Italy) in the reconstruction plan: Hypothesis of adaptive Reuse. In Int Arch. Photogramm. Remote Sens. Spatial Inf. Sci., n. XLIV -M-I-2020, pp. 929-936.

Varagnoli C. (2009). Muri parlanti. Prospettive per l'analisi e la conservazione dell'edilizia storica. Firenze: Alinea editrice.

Veninata C. (2020). Dal Catalogo generale dei beni culturali al knowledge graph del patrimonio culturale italiano: il progetto ArCo. In Digltalia, n. 2, pp. 43-56.

Zalamea Patino O. P., Van Orshoven J., Steenberghen T. (2018). Merging and expanding existing ontologies to cover the Built Cultural Heritage domain. In Journal of Cultural Heritage Management and Sustainable Development, n. 8(2), pp. I62-I78.

Zordan L. et al. (2002). Le tradizioni del costruire della casa in pietra: materiali, tecniche, modelli e sperimentazioni. L'Aquila: Università degli Studi dell'Aquila, Dipartimento di Architettura e Urbanistica.

\section{Authors}

llaria Trizio, Istituto per le Tecnologie della Costruzione, CNR L'Aquila (AQ), ilaria.trizio@itc.cnr.it Adriana Marra, Istituto per le Tecnologie della Costruzione, CNR L'Aquila (AQ), marra@itc.cnr.it: Francesca Savini, Istituto per le Tecnologie della Costruzione, CNR L'Aquila (AQ), savini@itc.cnr.it Andrea Ruggieri, Università degli Studi del Molise, a.ruggieri3@studenti.unimol.it

To cite this chapter. Trizio Ilaria, Marra Adriana, Savini Francesca, Ruggieri Andrea. (2021). L'architettura vernacolare e i suoi linguaggi: verso un'ontologia dei centri storici minori/The vernacular architecture and its languages: towards an ontology of the minor historic centres. In Arena A., Arena M. Mediati D. Raffa P. (a cura di). Connettere. Un disegno per annodare e tessere. Linguaggi Distanze Tecnologie. Atti del $42^{\circ}$ Convegno Internazionale dei Docenti delle Discipline della Rappresentazione/Connecting. Drawing for weaving relationship. Languages Distances Technologies. Proceedings of the $42^{\text {th }}$ International Conference of Representation Disciplines Teachers. Milano: FrancoAngeli, pp. $1198-1215$. 